Accepted author manuscript version reprinted, by permission, from International Journal of Sports Physiology and Performance, 2020. (C) Human Kinetics, Inc. The final published version is available at: https://doi.org/10.1123/ijspp.2019-0534

\title{
The influence of recruitment age, anthropometric and physical characteristics on the development pathway of English Academy football players
}

\begin{abstract}
Purpose: This study aims firstly to investigate the influence of recruitment age on retention and release across the development pathway. Secondly, the study aims to explore the influence of anthropometric and physical characteristics on retention and release at different ages throughout the development pathway and the likelihood of obtaining a professional contract. Methods: Following ethics approval, a crosssectional study tracking 4 cohorts of players over 5 years assessed 76 male youth football players (11-16 years) from an English football academy on three occasions annually in anthropometry, countermovement jump height, linear $(30 \mathrm{~m}$ and $15 \mathrm{~m})$ and multidirectional sprint time. Players were categorised based on their start and release date. Results: Starting early (i.e. before U12) in an academy was a key indicator of obtaining a professional contract, representing $87 \%$ of the players signed. Bayesian regression models suggest that the majority of differences in physical characteristics between players that were released and retained are trivial, small and / or uncertain. Players who attained a professional contract at 18 had slower $15 \mathrm{~m}$ and $30 \mathrm{~m}$ sprint times at U13-U15 ( $\mathrm{P}>0=0.87-0.99)$, slower multidirectional sprint times at $\mathrm{U} 14(\mathrm{P}>0=0.99)$ and a lower countermovement jump height at U13-U16 $(\mathrm{P}>0=0.88-0.99)$ compared with players who did not gain a contract. Conclusion: Players recruited early have an increased likelihood of gaining a professional contract. Physical assessments lack utility when used in isolation as a talent identification tool.
\end{abstract}

Keywords:

Talent identification; Talent development; Long term athletic development.

\section{Introduction}

Currently, 2.5 million boys engage in grassroots football in England and Wales of which $\sim 12,000$ players are selected to play in academies at professional clubs highlighting the scale of the talent identification and development process. ${ }^{1}$ Furthermore, the high attrition rates $(>75 \%)$ of players prior to the age of 21 indicate the opportunity to sustain a career in professional football is limited. ${ }^{2}$ High attrition rates have been reported in German Youth players (U11-U19) with less than 50\% of players still present within the system 3 years after recruitment, with a minority $(\sim 35 \%)$ of the players signing a professional contact recruited prior to U13. ${ }^{3}$ Yet, at present little is known regarding the attrition rates and the probability of obtaining a professional contract based on the age of recruitment in English academy systems.

In 2011, a long-term strategy, the Elite Player Performance Plan (EPPP), was introduced by the Premier League to develop elite youth football players in England and Wales. ${ }^{4}$ The aim of the EPPP was to provide homegrown players with the best facilities, environment and coaching to enhance player development with individual clubs investing up to $£ 5$ million annually into their talent development pathway. ${ }^{4}$ Within each academy, the talent development pathway reflects each player's journey 
in which the timing and tempo of technical, tactical, physical and psychological development differs and influences the timing of recruitment, release and retainment. 4,5 The introduction of the EPPP required football academies to benchmark their players'. Providing objective assessments to benchmark players technical, tactical, physical and psychological capabilities is challenging given the determinants of elite performance in football are multidimensional and complex. ${ }^{5,6,7}$ Given these challenges, physical assessments are often employed to benchmark players due to their simplicity and the challenges associated with quantifying other aspects of football performance objectively. The EPPP requires academies to schedule physical assessments at regular time points across a season and attempts to assess physical characteristics such as speed and power. ${ }^{8,9}$ At an elite level such characteristics are associated with the defining moments in the game in which players are required to produce high forces in a short period of time. ${ }^{10}$ As a consequence, data collated from physical assessments is utilised in coach reports and player reviews to assist staff in talent identification, player development and decisions upon retention and release. ${ }^{4,6}$

Previously it had been well documented that a selection bias exists in professional European clubs at youth level towards individuals who perform better in physical assessments. These individuals are more likely to be retained through the development pathway ${ }^{11,12}$ and attain a professional contract. ${ }^{12,13}$ In English academy players, a single study exists, assessing the influence of physical characteristics on whether the player was successful or unsuccessful in attaining a professional contract. Emmonds et al., $(2016){ }^{14}$ reported that English youth players who subsequently attained a professional contract had better physical characteristics at U16 and U18 but not before. Conversely, a recent study in Swiss players contradicts previous findings with evidence of an association between poorer physical characteristics 5 years prior to subsequent success in gaining a professional contract. ${ }^{15}$ Given these conflicting findings and the limited data presented within English academy players, further research is warranted.

Whilst previous cross-sectional studies provide a useful insight into the influence of physical characteristics on gaining a contract, little is known concerning these characteristics across the development journey. It is proposed, a retrospective research methodology which tracks career progression may assist and improve talent identification processes by potentially allowing researchers and practitioners to determine characteristics associated with future sporting success. ${ }^{16}$ Given that talent identification is a dynamic process in which players are continually recruited throughout the development pathway and retained or released on an annual or bi-annual basis, previous studies have not carried out a cross-sectional analysis which tracks cohorts of players through their academy journey accounting for these transition points. Hence, using a cross-sectional analysis to retrospectively track 4 cohorts of players, this study aimed firstly to investigate the influence of recruitment age on retention and release across the development pathway in an English football academy. Secondly, the study aimed to explore the influence of anthropometric and physical characteristics on retention and release at different age categories throughout the development pathway and the likelihood of obtaining a professional contract.

\section{Methods}

Participants

Seventy-six male youth football players (age range: 11-16 years) from an English Category two academy, participated in the study. All Players who participated in the 
study were born between 1996 and 2000 and signed for the club for a minimum of one year during the Youth Development Phase (ages 11 to 16). Players training consisted of between 6-10 h per week and one competitive match. The study was inclusive of all playing positions, including goalkeepers $(n=6)$. The study was approved by an institutional ethics committee.

\section{Experimental design}

In a cross-sectional study design, 4 cohorts of players were assessed over 5 years (U12 to U16) in anthropometry and physical performance on three occasions throughout the year (September, January and April) between 2008 and 2016. All players signed at the academy in the Youth Development Phase during this period participated in a minimum of one assessment per year at U12, U13, U14, U15 and / or U16 age groups. For each player, the best score attained at a given time point each season was used in the analysis. Age groups were determined by birth date with an annual cut-off date of the $31^{\text {st }}$ August. Players were assigned to groups based on their start date and release date at the academy. The majority of retention and release decisions in the Youth Development Phase were made at the end of U12, U14 and U16 age groups, with some decisions made at U13 and U15. A decision on whether players gained a professional contract or not was made after players had spent 2 years training on a full time basis with the club in the U18 age group. Hence, players were assigned groups based on when they signed for the academy 1) Signed at U12 or prior (present in the U12s age group), 2) Signed in U13 or U14 age groups, 3) Signed in the U15 or U16 age group. players were also assigned to one of five groups for retention and release 1) released at U12,2) released at $\mathrm{U} 13$ or $\mathrm{U} 14,3)$ released at $\mathrm{U} 15$ or $\mathrm{U16}, 4)$ released at $\mathrm{U} 18$ 5) signed a professional contract. Table 1 outlines the number of players signed and released at a given age group between U12 and U18. Table 2 outlines the number of players for whom repeated assessments were carried out. Throughout the study some players did not take part in a given assessment as a result of the player being released early or not being present at the testing sessions (U12 released $n=0$, retained $n=4 ; U 14$ released $n=7$, retained $n=4$; $\mathrm{U} 16$ released $\mathrm{n}=15$, retained $\mathrm{n}=1$ ).

***Table 1 and 2 near here $* * *$

\section{Procedures}

At each assessment point, anthropometrics were assessed prior to any physical performance assessments. Stature (Marsden HM-250P portable height measure, Rotherham, United Kingdom) and body mass (Seca 875, Hamburg, Germany) were measured in light clothing to the nearest $0.1 \mathrm{~cm}$ and $0.1 \mathrm{~kg}$, respectively. The battery of performance assessments included $15 \mathrm{~m}$ and $30 \mathrm{~m}$ sprints, a countermovement jump (CMJ) and an assessment of multi-directional speed (Arrowhead agility test; AAT). All players were familiarised with the assessments, there was a 5-minute intermission between each of the assessments and at every assessment point the order of the tests was the same 1) CMJ, 2) Sprints, 3) AAT. Before all testing procedures, players completed a 10 min warm-up which consisted of running at various speeds and dynamic stretching.

The CMJ was carried out on a contact mat (Fusion Sport, Canberra, Australia). Each player completed three warm-up jumps followed by three maximal unloaded CMJ with 
a $\sim 5$-second intermission between each jump. ${ }^{17}$ Players wore trainers and following a demonstration were instructed to perform a maximal vertical jump. No prior information or feedback was given to the players with regard to jump technique. However, jumps were disqualified if players attempted to manipulate flight time in any way. Following a disqualified jump, players were given the opportunity to perform the $\mathrm{CMJ}$ again after a $\sim 20$-second intermission, during which time corrective feedback was provided. Jump height was calculated using flight time and the best jump was recorded.

The sprints and AAT were carried out on an indoor $3 \mathrm{G}$ surface with all players wearing football boots. Players carried out three sprints which were recorded by infra-red timing gates (Fusion Sport, Canberra, Australia) at $15 \mathrm{~m}$ and $30 \mathrm{~m}$ intervals. The start line was set $0.5 \mathrm{~m}$ before the initial set of timing gates. Each player completed $\sim 4$ minutes passive recovery period between each sprint. The fastest time achieved in the three sprints was used in subsequent analysis. The AAT was carried out as previously described. ${ }^{17}$ In brief, players ran a 37.3 m course with 3 changes of direction as quickly as possible. The start line was set $0.5 \mathrm{~m}$ before the initial set of timing gates. Players completed four runs in total, two with an initial movement to the left or right respectively, with a $\sim 4$ minute passive recovery period between each run. The fastest time achieved in the four runs was used in subsequent analysis.

\section{Statistical analysis}

Descriptive statistics are presented in three forms: 1) as a total number of players obtaining a professional contract or being released. 2) as means \pm standard deviations (SD) of age, stature, body mass, CMJ height, linear and multidirectional sprint times depending on whether players were retained or released by the academy at particular ages (U12, U14, U16). 3) as means \pm standard deviations (SD) of age, stature, body mass, CMJ height, linear and multidirectional sprint times at each retrospective age (U12, U13, U14, U15, U16) depending on whether players subsequently gained a professional contract or not.

To determine the probability of players being released from the academy or being signed to a professional contract, several different Bayesian models were fitted with different link functions and combinations of predictors. Leave-One-Out crossvalidation (LOO) was used to determine the best model for each of the research questions posed.

The probability of players being released from the academy given the age they joined, was modelled using a Bayesian ordinal regression with age at release the dependent variable and age on entering the academy the predictor. This model was fitted using a Bernoulli distribution (no: still playing beyond time t; yes: released at time $\mathrm{t}$ ) using a complementary log-log link. When the probability of release is extremely small or large at particular times, the linear relationship does not hold. Therefore, a complementary $\log -\log$ link is an appropriate link function, and this proved the best model fit. The probability of a player obtaining a professional contract given the year they joined the academy was modelled using Bayesian logistic regression, with obtaining a professional contract or not $(1=$ contract, $0=$ no contract $)$ the dependent variable and age on entering the academy the predictor.

To determine the probability of the players' measured anthropometric and physical characteristics influencing whether a player: 1) is released or retained by the academy 
2) is successful or not in obtaining a professional contract, a series of Bayesian models were fitted. Firstly, the models were used to determine differences in physical characteristics of those retained compared to those released at different ages (U12, U14, U16). Secondly, the models were used to determine differences in physical characteristics measured at U12, U13, U14, U15 and U16 of those players who were successful or not in subsequently obtaining a professional contract at U18. Differences were modelled for stature, body mass, sprint times, multi-directional sprint times and CMJ heights. The probability that the difference is greater than zero $(\mathrm{P}>0)$ or less than zero $(\mathrm{P}<0)$ were calculated. Effect sizes were calculated using Cohens' $\mathrm{d}$ with a Hedges $\mathrm{g}$ correction which were defined as trivial (0.00-0.19), small (0.20-0.59), large (0.60 $1.19)$, very large $(\geq 1.2){ }^{18}$

All analyses were conducted using $\mathrm{R}$ and the brms package. ${ }^{19}$ All models were checked for convergence $(\hat{r}=1)$, with the graphical posterior predictive checks showing simulated data under the best fitted models compared well to the observed data with no systematic discrepancies. ${ }^{20}$

\section{Results}

Age of recruitment

The results of the Bayesian ordinal regression model suggest those recruited to the academy under 12 years of age, have a very low probability of being released at the end of the U12s age group ( $\mathrm{p}=0.04)$, but the probability of release increases at the end of the U14s age group ( $\mathrm{p}=0.36)$, is higher still at the end of the U16s age group ( $\mathrm{p}=0.48)$, lowering again for release at the end of the U18s age group $(\mathrm{p}=0.12)$. For players starting the academy at 12-14 years of age, the probability of being released at the end of the U14s age group is relatively high $(\mathrm{p}=0.30)$. Similar to those recruited under 12 , the probability of release is highest at the end of the U16s age group $(\mathrm{p}=0.48)$, reducing again at the end of the U18s age group $(\mathrm{p}=0.19)$.

The total number of players signing a professional contract at 18 years was $16(21.1 \%$ of all players signed at the academy), of which 13 (17.1\% of all players signed at the academy) started the academy under 12 years of age. The results of the Bayesian logistic regression predicting how likely players are to get signed to a professional contract given the age they started the academy, suggests that those players starting the academy under 12 years of age are 12.43 times more likely to get signed to a professional contract than those starting at U13 and U14, and 3.16 times more likely than those players starting with the academy at U15 and U16. Those joining the academy at U15 and U16 are 3.82 times more likely to get signed than those joining at U13 and U14.

\section{Anthropometric and Physical characteristics}

Bayesian regression models revealed that many of the differences in anthropometric and physical characteristics between released and retained players at U12, U14 and U16 were trivial and uncertain (Table 3, Table 4, Table 5, Table 6). However, small differences in stature and body mass were observed at U16 with retained players smaller and lighter than released players $(\mathrm{P}<0=0.72$ and $\mathrm{P}<0=0.89)$. Small differences in $15 \mathrm{~m}$ and $30 \mathrm{~m}$ sprint times were observed at $\mathrm{U} 14(\mathrm{P}<0=0.66$ and $\mathrm{P}<0=0.79)$ and U16 $(\mathrm{P}<0=0.80$ and $\mathrm{P}<0=0.88)$ with retained players achieving faster sprint times than 
released players. Moderate differences in AAT at U12 and U16 were observed with retained players attaining faster sprint times than released players $(\mathrm{P}<0=0.99$ and $\mathrm{P}<0=0.91$ ). Also, a small difference in $\mathrm{CMJ}$ at $\mathrm{U} 12$ and $\mathrm{U} 14$ revealed retained players achieved a greater jump height than released players $(\mathrm{P}<0=0.85$ and $\mathrm{P}<0=0.90)$.

Players who obtained a professional contract were lighter and often outperformed by their less successful counterparts across the physical assessments (Table 7). Moderate differences in body mass were observed with lighter players at U13, U14, U15 and U16 $(\mathrm{P}>0=0.95$ to $\mathrm{P}>0=0.98$, Table 9 ) subsequently obtaining a professional contract. Differences in physical characteristics, measured within each age group (U12, U13, U14, U15 and U16), revealed small and moderate differences in $15 \mathrm{~m}$ and $30 \mathrm{~m}$ sprint time with players who subsequently attained a professional contract achieving slower $15 \mathrm{~m}$ and $30 \mathrm{~m}$ sprint times at U13, U14 and U15 (P $>0=0.87$ to $\mathrm{P}>0=0.99$, Table 10 and Table 11). Small to moderate differences were observed in CMJ height with players who subsequently attained a professional contract achieving a lower jump height at $\mathrm{U13}$, U14, $\mathrm{U} 15$ and $\mathrm{U} 16$ ( $\mathrm{P}>0=0.88$ to $\mathrm{P}>0=0.99$, Table 12$)$. A moderate difference in multidirectional sprint time at U14 highlighted players who subsequently attained a professional contract achieved slower multidirectional sprint time $(\mathrm{P}>0=0.99$, Table $13)$.

***Table 3-13 near here***

\section{Discussion}

The present study: (1) investigated the influence of recruitment age on retention and release across the development pathway and (2) explored the influence of anthropometric and physical characteristics on retention and release at different ages throughout the development pathway and the likelihood of obtaining a professional contract. This study furthers previous work on the influence of recruitment age ${ }^{3}$ and physical characteristics on future career progression ${ }^{12,13,14}$ in English academy football players.

\section{Age of recruitment}

This is the first study to examine the influence of recruitment age on retention and release in English football academy players and suggests that starting early in an academy is a key indicator of getting signed to a professional contract. More players were recruited under 12 years of age than at any other age, with $58 \%$ of players starting the academy at this age or prior of which $30 \%$ subsequently obtained a professional contract. In contrast with the present study, Gullich $(2014)^{3}$ reported players were less likely to gain a contract if they were recruited into the German Talent Promotion pathway early, with only $11 \%$ of players recruited prior to U12 attaining a professional contract. Whilst speculative, it has been suggested selection later during adolescence could be a more accurate indicator of future sporting success due to the many factors which influence development that change over time. ${ }^{21}$ However, talent development programmes in other sports have also suggested a potential advantage to early selection, with a prolonged involvement in such programmes potentially improving the chances of future career success. ${ }^{16}$ Whilst it is difficult to ascertain why a higher number of players recruited into the academy early subsequently gained a professional contract in the present study, a number of factors such as genetics, ${ }^{5}$ greater volume and specificity of practice, ${ }^{22}$ earlier exposure to the social and cultural influences of an academy, ${ }^{23}$ 
coach bias towards players who they have invested more time in, differences in national development models ${ }^{4}$ and club values and beliefs ${ }^{24}$ may warrant further investigation.

\section{Anthropometric and Physical characteristics}

The secondary aim of this study was to investigate the influence of anthropometric and physical characteristics on retention and release at different ages throughout the development pathway and the likelihood of obtaining a professional contract. While previous studies in Spain $^{11}$ and Belgium ${ }^{13}$ have investigated the influence of anthropometric and physical characteristics on retention and release in youth football players; this study is the first in English players. The findings showed that many of anthropometric and physical differences between players released and retained at different time points in the development pathway were trivial and uncertain. However, a small difference in stature and body mass revealed smaller and lighter players were retained at U16. In addition, a small difference in $15 \mathrm{~m}$ and $30 \mathrm{~m}$ sprint times at U14 and U16, a moderate difference in AAT at U12 and U16 and a small difference in CMJ at U12 and U14 was evident with retained players performing better than released players.

The present findings show better performance in some physical assessments (AAT, $15 \mathrm{~m}$ sprint, $30 \mathrm{~m}$ sprint and $\mathrm{CMJ}$ ) at specific ages were associated with retained players, yet this was not consistent across age groups or all physical characteristics. Previous studies in European youth football players have suggested an association between better physical characteristics and retention ${ }^{11,13}$. Deprez et al. $(2015)^{13}$ reported retained players attained better 30m sprint times at U12, U13, U14, U15 and U16 and CMJ at U13, U14 and U15. As such, anaerobic physical characteristics (strength, power and linear and multidirectional speed) which influence general movement patterns (i.e running, jumping) and within match outcomes (i.e tackling, finishing) critical to the defining moments in the game may influence the selection process. ${ }^{10,25}$ However, the disparity in these findings across age and physical assessments could be explained by the strategy employed by each academy in terms of the type of players they are looking to recruit and develop. Given the complex and multidimensional interaction of technical, tactical, physical and psychological factors which define each player's performance is not tangible, each club's approach to player selection is likely to vary based on each clubs values, beliefs and the coaches opinions. ${ }^{5,15}$

It is also important to consider that players may need to display a certain level of physical characteristics to enter the academy system. Players signed at an English Academy (U9-U21) have been found to exhibit better physical characteristics (CMJ height, $10 \mathrm{~m}$ and $20 \mathrm{~m}$ sprint time) compared with recreational players, ${ }^{26}$ however, this threshold is likely to change based on the individual's technical, tactical and psychological strengths and weaknesses. The present study suggests that, following the entry into an academy, exhibiting better physical characteristics compared to their academy peers is not a pre-requisite for players to progress through an English academy system. Hence, understanding and developing a holistic approach which assesses and benchmarks the complexity of the multidimensional aspects of football performance and player development is required. ${ }^{6,7,15}$

Another key finding in the present study was physical characteristics assessed in each year of the development pathway revealed players who subsequently attained a professional contract were lighter in body mass and did not perform as well in physical assessments. Equivocal findings in European youth players have reported superior, ${ }^{12,13}$ 
inferior, ${ }^{15}$ and no differences, ${ }^{27}$ in physical characteristics at U13, U14, U15 and U16 between players subsequently achieving a professional contract and released players. Emmonds (2016) ${ }^{14}$ reported English academy players who attained professional status at 18 attained faster sprint times at U16, although no differences were evident between U12 and U15s in sprint speed. Similar to the findings of the present study, Sieghartsleitner $(2019)^{15}$ reported more inferior physical characteristics (yoyo test, $\mathrm{CMJ}$ and linear and multidirectional) were associated with subsequently gaining a professional contract in players on the Swiss elite development programme. Hence, potentially an 'underdog hypothesis ${ }^{28}$ may exist in which players with more inferior physical characteristics must adapt and develop certain technical, tactical or psychological aspects to overcome their physical disadvantage.

The equivocal findings in the present study and previous research may be explained by the aforementioned strategic approach of each academy. Additionally, the instability of physical characteristics due to differences in biological maturity between the ages of 12 and 16 years may fail to represent physical characteristics in later years. ${ }^{29,30}$ Consequently coaches face a challenge in their attempts to predict future ability at a given time point. Moreover, assessing physical performance can only provide a state measure i.e. performance potential at a given time point. These assessments fail to look beyond a players current state and fail to provide a holistic assessment of performance. This poses a problem to current talent identification and benchmarking given that performance characteristics develop non-linearly and are influenced by many factors such as maturity, relative age, genetics and the environment. ${ }^{5,24}$

As previously highlighted, a confounding factor influencing physical performance is maturity; therefore, a major limitation of the present study was the absence of a maturity assessment. A further limitation to the present study was that physical assessments were assessed at 3 time points in the year. However, not all players were present at all testing sessions, hence using the best score at any point in the year may have influenced performance in the physical assessments. Another limitation to the present study was the age of recruitment before U12 was not assessed. Therefore, players signed at the academy prior to U12 may have entered the academy any time between U7 and U11 age groups. Furthermore, the present study does not track long term success following players obtaining a professional contract. Hence, caution should be taken interpreting the findings given that the longevity of the players careers was not assessed.

\section{Practical Applications}

The present findings suggests coaches may need to be aware of the development opportunity that may be afforded to those recruited earlier in the development pathway when considering (de)selection given development is non-linear. Secondly, the present findings suggest physical assessments lack utility when used in isolation as a talent identification tool. Some physical assessments may differentiate between between those retained and released, however ultimately, this does not influence long term progression (gaining a professional contract). Hence, coaches may need to be cautious of physical biases when making decisions on retain and release and should employ a holistic approach when benchmarking players and consider the multidimensional aspects of football performance and development.

\section{Conclusion}


In conclusion, the findings suggest that players were more likely to gain a professional contract if they were recruited earlier to the academy. Establishing the key factors influencing player recruitment at different ages is a potential area for future research. Also, players' anthropometric and physical characteristics are not always associated with retention through the academy system and obtaining a professional contract. Further research is required to develop an understanding of the technical, tactical, physical and psychological factors that influence the talent identification process. Promising approaches have attempted to employ statistical approaches to address the multidimensional complexity of talent identification, ${ }^{15}$ however, such approaches require further research.

\section{Conflict of Interest}

There were no potential conflict of interest.

\section{References}

1. The state of the game - in numbers. The Football Association. 2015.

2. Monk, D., Olsson, C. Modern apprenticeships in professional football: some policy implications. Industrial and Commercial Training . 2007; 39(6): 319-324

3. Gullich A. Selection, de-selection and progression in German football talent promotion. Eur J Sport Sci. 2014;14(6):530-537.

4. $\quad$ The Elite Player Performance Plan. The Premier League. 2011.

5. Sarmento H, Anguera MT, Pereira A, Araujo D. Talent Identification and Development in Male Football: A Systematic Review. Sports Med. 2018;48(4):907-931.

6. Dodd K, Newans T. Talent identification for soccer: Physiological Aspects. $J$ Sci Med Sport. 2018;21(10):1073-1078.

7. Murr D, Feichtinger P, Larkin P, O`Connor D, Höner O. Psychological talent predictors in youth soccer: A systematic review of the prognostic relevance of psychomotor, perceptual-cognitive and personality-related factors. PloS one. 2018;13(10):e0205337.

8. Lovell R, Towlson C, Parkin G, Portas M, Vaeyens R, Cobley S. Soccer Player Characteristics in English Lower-League Development Programmes: The Relationships between Relative Age, Maturation, Anthropometry and Physical Fitness. PloS one. 2015;10(9): 0137238

9. Morris R, Emmonds S, Jones B, et al. Seasonal changes in physical qualities of elite youth soccer players according to maturity status: comparisons with aged matched controls. Science and Medicine in Football. 2018;2(4):272-280.

10. Silva JR, Nassis GP, Rebelo A. Strength training in soccer with a specific focus on highly trained players. Sports Med Open. 2015;1(1):17.

11. Lago-Peñas C, Rey E, Casáis L, Gómez-López M. Relationship Between Performance Characteristics and the Selection Process in Youth Soccer Players. J Hum Kinet. 2014;40:189-199.

12. Gonaus C, Muller E. Using physiological data to predict future career progression in 14- to 17-year-old Austrian soccer academy players. J Sports Sci. 2012;30(15):1673-1682.

13. Deprez DN, Fransen J, Lenoir M, Philippaerts RM, Vaeyens R. A retrospective study on anthropometrical, physical fitness, and motor coordination characteristics that influence dropout, contract status, and first-team playing time in high-level soccer players aged eight to eighteen years. J Strength Cond Res. 2015;29(6):1692-1704. 
14. Emmonds S, Till K, Jones B, Mellis M, Pears M. Anthropometric, speed and endurance characteristics of English academy soccer players: Do they influence obtaining a professional contract at 18 years of age? Int J Sports Sci Coaching. 2016;11(2):212-218.

15. Sieghartsleitner R, Zuber C, Zibung M, Conzelmann A. Science or Coaches' Eye? - Both! Beneficial Collaboration of Multidimensional Measurements and Coach Assessments for Efficient Talent Selection in Elite Youth Football. $J$ Sports Sci Med. 2019;18(1):32-43.

16. Till K, Cobley D, Morley, D., et al. The influence of age, playing position, anthropometry and fitness on career attainment outcomes in rugby league. $J$ Sports Sci. 2016;34(13);1240-1245.

17. Noon MR, James RS, Clarke ND, Akubat I, Thake CD. Perceptions of wellbeing and physical performance in English elite youth footballers across a season. J Sports Sci. 2015;33(20);2106-2115.

18. Hopkins, W. G., Marshall, S. W., Batterham, A. M. \& Hanin, J. Progressive statistics for studies in sports medicine and exercise science. Med Sci Sport Exerc. 2009, 41, 3-13.

19. Bürkner P-C. brms: An R Package for Bayesian Multilevel Models Using Stan. 2017. J Stat Softw. 2017;80(1):28.

20. Gabry J, Simpson D, Vehtari A, Betancourt M, Gelman A. Visualization in Bayesian workflow. J R Statsist Soc 2019;182(2):389-402.

21. Vaeyens, R., Lenoir, M., Williams, M.A., Philippaerts, R.M. Talent Identification and Development Programmes in Sport Current Models and Future Directions. Sports Med. 2008; 38 (9): 703-714

22. Ford PR, Ward P, Hodges NJ, Williams AM. The role of deliberate practice and play in career progression in sport: the early engagement hypothesis. High Ability Studies. 2009;20(1);65-75.

23. Morris R, Tod D, Oliver E. An Analysis of Organizational Structure and Transition Outcomes in the Youth-to-Senior Professional Soccer Transition. $J$ Appl Sport Psychol. 2015;27(2):216-234.

24. Horrocks DE, McKenna J, Whitehead A, Taylor PJ, Morley AM. Qualitative perspectives on how Manchester United Football Club developed and sustained serial winning. Int J Sports Sci Coaching. 2016;11(4):467-477.

25. Deprez D, Coutts AJ, Fransen J, et al. Relative age, biological maturation and anaerobic characteristics in elite youth soccer players. Int J Sports Med. 2013;34(10):897-903.

26. Murtagh CF, Brownlee TE, O'Boyle A, Morgans R, Drust B, Erskine RM. Importance of Speed and Power in Elite Youth Soccer Depends on Maturation Status. J Strength Cond Res. 2018;32(2):297-303.

27. Le Gall F, Carling C, Williams M, Reilly T. Anthropometric and fitness characteristics of international, professional and amateur male graduate soccer players from an elite youth academy. J Sci Med Sport. 2010;13(1):90-95.

28. Gibbs BG, Jarvis JA, Dufur MJ. The rise of the underdog? The relative age effect reversal among Canadian-born NHL hockey players: A reply to Nolan and Howell. IRSS. 2011;47(5):644-649.

29. Carling C, le Gall F, Reilly T, Williams AM. Do anthropometric and fitness characteristics vary according to birth date distribution in elite youth academy soccer players? Scand J Med Sci Spor. 2009;19(1):3-9. 
30. Malina RM, Rogol AD, Cumming SP, Coelho e Silva MJ, Figueiredo AJ. Biological maturation of youth athletes: assessment and implications. $\mathrm{Br} J$

\begin{tabular}{lccc}
\hline & Signed pre U12 & $\begin{array}{c}\text { Signed in U13 or U14 } \\
\text { age group }\end{array}$ & $\begin{array}{c}\text { Signed in U15 or U16 } \\
\text { age group }\end{array}$ \\
\hline Total & 44 & 25 & 7 \\
Released at U12 & $6(14 \%)$ & -- & --- \\
Released at U13/ U14 & $14(32 \%)$ & $6(24 \%)$ & -- \\
Released at U15/ U16 & $8(18 \%)$ & $14(56 \%)$ & $6(86 \%)$ \\
Released at U18 & $3(7 \%)$ & $3(12 \%)$ & $0(0 \%)$ \\
Signed professional contract & $13(30 \%)$ & $2(8 \%)$ & $1(14 \%)$ \\
\hline
\end{tabular}

Sports Med. 2015;49(13):852-859.

Table 1. Number of players signed and released at a given age group between U12 and U18 age at an English category 2 football academy.

Percentages presented in parenthesis

Table 2. The number of single or repeated assessments per year per player at a given age group.

\begin{tabular}{lccc} 
& Signed pre U12 & $\begin{array}{c}\text { Signed in U13 or U14 } \\
\text { age group }\end{array}$ & $\begin{array}{c}\text { Signed in U15 or U16 } \\
\text { age group }\end{array}$ \\
\hline 1 season & 6 & 3 & 3 \\
2 seasons & 8 & 10 & 4 \\
3 seasons & 8 & 9 & --- \\
4 seasons & 5 & 3 & --- \\
5 seasons & 17 & --- & --- \\
\hline
\end{tabular}


Table 3. Mean \pm SD for age, stature, body mass, countermovement jump (CMJ) height, sprint times and arrowhead agility (AAT) times, depending on whether players were retained or released by a category 2 football academy.

\begin{tabular}{|c|c|c|c|c|c|c|}
\hline \multirow[b]{3}{*}{ Measure } & \multicolumn{2}{|c|}{ U12 } & \multicolumn{2}{|c|}{ U14 } & \multicolumn{2}{|c|}{ U16 } \\
\hline & $\begin{array}{l}\text { Released } \\
(n=6)\end{array}$ & $\begin{array}{l}\text { Retained } \\
(\mathrm{n}=34)\end{array}$ & $\begin{array}{l}\text { Released } \\
(n=14)\end{array}$ & $\begin{array}{l}\text { Retained } \\
(\mathrm{n}=38)_{-}\end{array}$ & $\begin{array}{l}\begin{array}{l}\text { Released } \\
(n=12)\end{array} \\
\end{array}$ & $\begin{array}{l}\text { Retained } \\
(\mathrm{n}=21)\end{array}$ \\
\hline & Mean \pm SD & Mean \pm SD & Mean \pm SD & Mean \pm SD & Mean \pm SD & Mean \pm SD \\
\hline Age (years) & $11.79 \pm 0.17$ & $11.79 \pm 0.45$ & $13.74 \pm 0.27$ & $13.69 \pm 0.41$ & $15.68 \pm 0.68$ & $15.75 \pm 0.49$ \\
\hline Stature $(\mathrm{cm})$ & $151.3 \pm 4.7$ & $153.0 \pm 10.2$ & $169.0 \pm 10.1$ & $168.8 \pm 9.1$ & $177.5 \pm 5.5$ & $175.6 \pm 8.0$ \\
\hline Body mass (kg) & $41.3 \pm 5.2$ & $42.0 \pm 8.2$ & $56.9 \pm 9.2$ & $57.0 \pm 9.8$ & $68.6 \pm 8.6$ & $64.5 \pm 8.0$ \\
\hline $15 \mathrm{~m}$ sprint (s) & $2.79 \pm 0.13$ & $2.78 \pm 0.21$ & $2.61 \pm 0.13$ & $2.58 \pm 0.12$ & $2.52 \pm 0.12$ & $2.49 \pm 0.08$ \\
\hline $30 \mathrm{~m}$ sprint (s) & $4.95 \pm 0.14$ & $4.94 \pm 0.21$ & $4.63 \pm 0.20$ & $4.56 \pm 0.24$ & $4.37 \pm 0.20$ & $4.28 \pm 0.39$ \\
\hline $\mathrm{CMJ}(\mathrm{cm})$ & $33.3 \pm 2.6$ & $35.6 \pm 4.9$ & $39.7 \pm 3.7$ & $40.7 \pm 5.1$ & $46.0 \pm 5.9$ & $44.6 \pm 7.4$ \\
\hline $\operatorname{AAT}(\mathrm{s})$ & $9.32 \pm 0.22$ & $8.96 \pm 0.31$ & $8.58 \pm 0.33$ & $8.63 \pm 0.27$ & $8.36 \pm 0.30$ & $8.22 \pm 0.17$ \\
\hline
\end{tabular}

Players not included in analysis due not being present at testing sessions or release at U13 or U15 (U12 released $n=0$, retained $n=4$; $U 14$ released $n=7$, retained $n=4$; U16 released $n=15$, retained $n=1$ )

Table 4. Bayesian estimates for differences between players retained and players released at U12 at an English category 2 football academy.

\begin{tabular}{ccccccc}
\hline Measure & Released & Retained & $\begin{array}{c}\text { Difference } \\
(95 \% \text { HDI })\end{array}$ & ES & $\mathrm{p}<0$ & $\mathrm{p}>0$ \\
\hline Stature $(\mathrm{cm})$ & 151.2 & 153.0 & $1.8(-4.7,8.0)$ & 0.18 & 0.66 & 0.34 \\
Body mass $(\mathrm{kg})$ & 41.3 & 42.0 & $0.7(-5.7,7.0)$ & 0.09 & 0.66 & 0.34 \\
15m sprint (s) & 2.79 & 2.78 & $-0.01(-0.17,0.13)$ & 0.05 & 0.57 & 0.43 \\
30m sprint (s) & 4.95 & 4.94 & $-0.01(-0.19,0.17)$ & 0.05 & 0.55 & 0.45 \\
CMJ (cm) & 33.4 & 35.6 & $2.2(-1.0,5.5)$ & 0.47 & 0.85 & 0.15 \\
AAT (s) & 9.31 & 8.96 & $-0.35(-0.63,-0.07)$ & 1.16 & 0.99 & 0.01 \\
\hline
\end{tabular}

Difference $=$ estimated mean difference, $95 \% \mathrm{HDI}=95 \%$ higher density interval, ES = Cohen's d effect size, $\mathrm{P}>0$ probability the differences are greater than 0 (released group taller, heavier, faster and jumping higher), $\mathrm{P}<0$ probability differences are less than 0 (retained group taller, heavier, faster and jumping higher). 
Table 5. Bayesian estimates for differences between players retained and players released at U14 at an English category 2 football academy.

\begin{tabular}{ccccccc}
\hline Measure & Released & Retained & $\begin{array}{c}\text { Difference } \\
(95 \% \text { HDI })\end{array}$ & ES & $\mathrm{p}<0$ & $\mathrm{p}>0$ \\
\hline Stature (cm) & 169.0 & 168.9 & $-0.1(-7.6,5.9)$ & 0.02 & 0.48 & 0.52 \\
Body mass (kg) & 56.9 & 57.0 & $0.1(-5.9,7.6)$ & 0.01 & 0.51 & 0.49 \\
15m sprint (s) & 2.61 & 2.59 & $-0.02(-0.11,0.07)$ & 0.24 & 0.66 & 0.34 \\
30m sprint (s) & 4.63 & 4.56 & $-0.07(-0.26,0.11)$ & 0.30 & 0.79 & 0.21 \\
CMJ (cm) & 39.1 & 40.9 & $1.8(-1.0,4.5)$ & 0.21 & 0.90 & 0.10 \\
AAT (s) & 8.58 & 8.63 & $0.05(-0.17,0.28)$ & 0.17 & 0.31 & 0.69 \\
\hline
\end{tabular}

Difference = estimated mean difference, 95\%HDI = 95\% higher density interval, ES = Cohen's d effect size, $\mathrm{P}>0$ probability the differences are greater than 0 (released group taller, heavier, faster and jumping higher), $\mathrm{P}<0$ probability differences are less than 0 (retained group taller, heavier, faster and jumping higher).

Table 6. Bayesian estimates for differences between players retained and players released at U16 at an English category 2 football academy.

\begin{tabular}{ccccccc}
\hline Measure & released & retained & $\begin{array}{c}\text { Difference } \\
(95 \% \text { HDI })\end{array}$ & ES & $\mathrm{p}<0$ & $\mathrm{p}>0$ \\
\hline Stature $(\mathrm{cm})$ & 177.5 & 175.6 & $-1.9(-7.9,4.1)$ & 0.26 & 0.28 & 0.72 \\
Body mass $(\mathrm{kg})$ & 68.6 & 64.4 & $-4.2(-11.3,2.8)$ & 0.51 & 0.11 & 0.89 \\
15m sprint (s) & 2.52 & 2.49 & $-0.03(-0.12,0.06)$ & 0.31 & 0.80 & 0.20 \\
30m sprint (s) & 4.37 & 4.28 & $-0.09(-0.23,0.07)$ & 0.27 & 0.88 & 0.12 \\
CMJ (cm) & 46.0 & 44.6 & $-1.4(-6.6,4.1)$ & 0.20 & 0.30 & 0.70 \\
AAT (s) & 8.36 & 8.22 & $-0.14(-0.34,0.06)$ & 0.62 & 0.91 & 0.09 \\
\hline
\end{tabular}

Difference $=$ estimated mean difference, $95 \%$ HDI $=95 \%$ higher density interval, ES = Cohen's d effect size, $\mathrm{P}>0$ probability the differences are greater than 0 (released group taller, heavier, faster and jumping higher), $\mathrm{P}<0$ probability differences are less than 0 (retained group taller, heavier, faster and jumping higher). 
Table 7. Mean \pm SD for age, stature, body mass, countermovement jump (CMJ) height, sprint times and arrowhead agility (AAT) times, depending on whether players were subsequently successful or not in gaining a professional contract at category 2 football academy.

\begin{tabular}{|c|c|c|c|c|c|c|c|c|}
\hline $\begin{array}{l}\text { Age } \\
\text { grou } \\
\mathrm{p}\end{array}$ & & Age (Years) & Stature $(\mathrm{cm})$ & Body Mass (kg) & $15 \mathrm{~m}$ Sprint (s) & 30m Sprint (s) & $\mathrm{CMJ}(\mathrm{cm})$ & $\operatorname{AAT}(\mathrm{s})$ \\
\hline \multirow[t]{2}{*}{ U12 } & $\begin{array}{c}\text { No contract } \\
(n=28)\end{array}$ & $\begin{array}{c}11.8 \pm 0.5 \\
(n=23)\end{array}$ & $\begin{array}{c}153.7 \pm 8.5 \\
(n=23)\end{array}$ & $\begin{array}{c}42.8 \pm 7.5 \\
(n=23)\end{array}$ & $\begin{array}{c}2.79 \pm 0.15 \\
(n=28)\end{array}$ & $\begin{array}{c}4.94 \pm 0.22 \\
(n=28)\end{array}$ & $\begin{array}{c}35.7 \pm 5.2 \\
(n=27)\end{array}$ & $\begin{array}{c}9.09 \pm 0.31 \\
(n=21)\end{array}$ \\
\hline & $\begin{array}{l}\text { Contract } \\
(n=12)\end{array}$ & $\begin{array}{c}11.7 \pm 0.2 \\
(n=12)\end{array}$ & $\begin{array}{c}150.9 \pm 11.9 \\
(n=12)\end{array}$ & $\begin{array}{c}40.0 \pm 8.1 \\
(n=12)\end{array}$ & $\begin{array}{c}2.77 \pm 0.11 \\
\quad(n=12)\end{array}$ & $\begin{array}{c}4.94 \pm 0.17 \\
(n=12)\end{array}$ & $\begin{array}{c}34.2 \pm 3.3 \\
(n=11)\end{array}$ & $\begin{array}{c}8.83 \pm 0.40 \\
(n=7)\end{array}$ \\
\hline \multirow[t]{2}{*}{ U13 } & $\begin{array}{c}\text { No contract } \\
(n=37)\end{array}$ & $\begin{array}{c}12.8 \pm 0.5 \\
(n=28)\end{array}$ & $\begin{array}{c}163.3 \pm 8.9 \\
(n=36)\end{array}$ & $\begin{array}{c}52.2 \pm 9.6 \\
(n=35)\end{array}$ & $\begin{array}{c}2.64 \pm 0.16 \\
(n=36)\end{array}$ & $\begin{array}{c}4.70 \pm 0.44 \\
(n=36)\end{array}$ & $\begin{array}{c}38.7 \pm 6.3 \\
(n=35)\end{array}$ & $\begin{array}{c}8.73 \pm 0.34 \\
(n=30)\end{array}$ \\
\hline & $\begin{array}{l}\text { Contract } \\
(n=14)\end{array}$ & $\begin{array}{c}12.7 \pm 0.4 \\
(n=13)\end{array}$ & $\begin{array}{c}159.4 \pm 11.4 \\
(n=13)\end{array}$ & $\begin{array}{c}47.1 \pm 9.1 \\
(n=13)\end{array}$ & $\begin{array}{c}2.73 \pm 0.13 \\
\quad(n=14)\end{array}$ & $\begin{array}{c}4.83 \pm 0.21 \\
(n=14)\end{array}$ & $\begin{array}{c}35.7 \pm 4.1 \\
(n=13)\end{array}$ & $\begin{array}{c}8.81 \pm 0.28 \\
(n=7)\end{array}$ \\
\hline \multirow[t]{2}{*}{ U14 } & $\begin{array}{l}\text { No contract } \\
\quad(n=36)\end{array}$ & $\begin{array}{c}13.7 \pm 0.4 \\
(n=29)\end{array}$ & $\begin{array}{c}170.1 \pm 8.4 \\
(n=34)\end{array}$ & $\begin{array}{c}58.7 \pm 8.8 \\
(n=34)\end{array}$ & $\begin{array}{c}2.57 \pm 0.13 \\
(n=35)\end{array}$ & $\begin{array}{c}4.53 \pm 0.25 \\
(n=35)\end{array}$ & $\begin{array}{c}41.2 \pm 4.8 \\
(n=34)\end{array}$ & $\begin{array}{c}8.55 \pm 0.29 \\
\quad(n=29)\end{array}$ \\
\hline & $\begin{array}{c}\text { Contract } \\
(n=15)\end{array}$ & $\begin{array}{c}13.7 \pm 0.3 \\
(n=15)\end{array}$ & $\begin{array}{c}165.6 \pm 11.1 \\
(n=15)\end{array}$ & $\begin{array}{c}52.6 \pm 10.3 \\
(n=15)\end{array}$ & $\begin{array}{c}2.65 \pm 0.11 \\
(n=15)\end{array}$ & $\begin{array}{c}4.69 \pm 0.21 \\
(n=15)\end{array}$ & $\begin{array}{c}38.7 \pm 4.4 \\
(n=14)\end{array}$ & $\begin{array}{c}8.78 \pm 0.21 \\
(n=8)\end{array}$ \\
\hline \multirow[t]{2}{*}{ U15 } & $\begin{array}{l}\text { No contract } \\
\qquad(n=33)\end{array}$ & $\begin{array}{c}14.8 \pm 0.4 \\
(n=32)\end{array}$ & $\begin{array}{c}174.4 \pm 5.7 \\
(n=31)\end{array}$ & $\begin{array}{c}63.9 \pm 6.5 \\
(n=31)\end{array}$ & $\begin{array}{c}2.46 \pm 0.10 \\
(n=33)\end{array}$ & $\begin{array}{c}4.33 \pm 0.19 \\
(n=33)\end{array}$ & $\begin{array}{c}45.9 \pm 5.4 \\
(n=33)\end{array}$ & $\begin{array}{c}8.43 \pm 0.27 \\
(n=33)\end{array}$ \\
\hline & $\begin{array}{l}\text { Contract } \\
(n=15)\end{array}$ & $\begin{array}{c}14.7 \pm 0.3 \\
(n=15)\end{array}$ & $\begin{array}{c}171.4 \pm 10.0 \\
(n=15)\end{array}$ & $\begin{array}{c}56.9 \pm 9.4 \\
(n=15)\end{array}$ & $\begin{array}{c}2.52 \pm 0.08 \\
(n=15)\end{array}$ & $\begin{array}{c}4.45 \pm 0.15 \\
(n=15)\end{array}$ & $\begin{array}{c}41.5 \pm 5.3 \\
(n=15)\end{array}$ & $\begin{array}{c}8.49 \pm 0.25 \\
\quad(n=15)\end{array}$ \\
\hline \multirow[t]{2}{*}{ U16 } & $\begin{array}{l}\text { No contract } \\
\quad(n=17)\end{array}$ & $\begin{array}{c}15.8 \pm 0.5 \\
(n=17)\end{array}$ & $\begin{array}{c}177.2 \pm 5.3 \\
(n=13)\end{array}$ & $\begin{array}{c}68.6 \pm 7.5 \\
(n=14)\end{array}$ & $\begin{array}{c}2.49 \pm 0.11 \\
(n=17)\end{array}$ & $\begin{array}{c}4.33 \pm 0.22 \\
(n=17)\end{array}$ & $\begin{array}{c}46.6 \pm 7.7 \\
(n=17)\end{array}$ & $\begin{array}{c}8.29 \pm 0.27 \\
(n=17)\end{array}$ \\
\hline & $\begin{array}{c}\text { Contract } \\
(n=16)\end{array}$ & $\begin{array}{c}15.6 \pm 0.3 \\
(n=16)\end{array}$ & $\begin{array}{c}175.2 \pm 8.7 \\
(n=16)\end{array}$ & $\begin{array}{c}63.1 \pm 8.2 \\
(n=16)\end{array}$ & $\begin{array}{c}2.50 \pm 0.08 \\
(n=16)\end{array}$ & $\begin{array}{c}4.30 \pm 0.13 \\
(n=16)\end{array}$ & $\begin{array}{c}43.6 \pm 5.8 \\
(n=15)\end{array}$ & $\begin{array}{c}8.26 \pm 0.18 \\
(n=16)\end{array}$ \\
\hline
\end{tabular}

Player numbers presented for each group or assessment $(n=)$.

Table 8. Bayesian estimates of stature at different ages between players who were subsequently successful in gaining a professional contract and players who did not gain a professional contract at an English category 2 football academy.

\begin{tabular}{ccccccc}
\hline $\begin{array}{c}\text { Age } \\
\text { group }\end{array}$ & $\begin{array}{c}\text { Stature } \\
\text { no contract } \\
(\mathrm{cm})\end{array}$ & $\begin{array}{c}\text { Stature } \\
\text { contract } \\
(\mathrm{cm})\end{array}$ & $\begin{array}{c}\text { Difference } \\
(95 \% \mathrm{HDI})\end{array}$ & $\mathrm{ES}$ & $\mathrm{P}<0$ & $\mathrm{P}>0$ \\
\hline $\mathrm{U} 12$ & 153.7 & 150.8 & $\begin{array}{c}-2.9(-11.3, \\
5.1)\end{array}$ & 0.29 & 0.24 & 0.76 \\
$\mathrm{U} 13$ & 163.3 & 159.5 & $\begin{array}{c}-3.8(-11.1, \\
3.5)\end{array}$ & 0.40 & 0.41 & 0.59 \\
$\mathrm{U} 14$ & 170.2 & 165.7 & $\begin{array}{c}-4.5(-11.4, \\
2.2)\end{array}$ & 0.47 & 0.36 & 0.64 \\
$\mathrm{U} 15$ & 174.5 & 171.5 & $\begin{array}{c}-3.0(-8.9, \\
3.0)\end{array}$ & 0.37 & 0.48 & 0.52 \\
$\mathrm{U} 16$ & 177.2 & 175.3 & $\begin{array}{c}-1.9(-7.4, \\
3.7)\end{array}$ & 0.27 & 0.22 & 0.78 \\
\hline
\end{tabular}

Difference $=$ estimated mean difference, $95 \%$ HDI $=95 \%$ higher density interval, ES $=$ Cohen's d effect size, $\mathrm{P}>0$ probability the differences are greater than 0 (no contract group taller), $\mathrm{P}<0$ probability the differences are less than 0 (contract group taller). 
Table 9. Bayesian estimates of body mass at different ages between players who were subsequently successful in gaining a professional contract and players who did not gain a professional contract at an English category 2 football academy.

\begin{tabular}{ccccccc}
\hline $\begin{array}{c}\text { Age } \\
\text { group }\end{array}$ & $\begin{array}{c}\text { Body mass } \\
\text { no contract } \\
(\mathrm{kg})\end{array}$ & $\begin{array}{c}\text { Body mass } \\
\text { contract } \\
(\mathrm{kg})\end{array}$ & $\begin{array}{c}\text { Difference } \\
(95 \% \mathrm{HDI})\end{array}$ & $\mathrm{ES}$ & $\mathrm{P}<0$ & $\mathrm{P}>0$ \\
\hline $\mathrm{U} 12$ & 42.8 & 40.0 & $\begin{array}{c}-2.7(-9.0, \\
3.6,)\end{array}$ & 0.36 & 0.19 & 0.81 \\
$\mathrm{U} 13$ & 52.2 & 47.2 & $\begin{array}{c}-5.1(-11.2, \\
1.2)\end{array}$ & 0.65 & 0.05 & 0.95 \\
$\mathrm{U} 14$ & 58.7 & 52.7 & $\begin{array}{c}-6.1(-12.4, \\
0.6)\end{array}$ & 0.66 & 0.04 & 0.96 \\
$\mathrm{U} 15$ & 64.0 & 57.0 & $\begin{array}{c}-7.0(-13.0, \\
1.2)\end{array}$ & 0.93 & 0.02 & 0.98 \\
$\mathrm{U} 16$ & 68.6 & 63.2 & $\begin{array}{c}-5.5(-11.8, \\
0.7)\end{array}$ & 0.67 & 0.04 & 0.96 \\
\hline
\end{tabular}

Difference $=$ estimated mean difference, $95 \%$ HDI $=95 \%$ higher density interval, ES = Cohen's d effect size, $\mathrm{P}>0$ probability the differences are greater than 0 (no contract group heavier), $\mathrm{P}<0$ the probability the differences are less than 0 (contract group heavier).

Table 10. Bayesian estimates of $15 \mathrm{~m}$ sprint times at different ages between players who were subsequently successful in gaining a professional contract and players who did not gain a professional contract at an English category 2 football academy.

\begin{tabular}{ccccccc}
\hline $\begin{array}{c}\text { Age } \\
\text { group }\end{array}$ & $\begin{array}{c}15 \mathrm{~m} \text { sprint } \\
\text { no contract } \\
(\mathrm{s})\end{array}$ & $\begin{array}{c}15 \mathrm{~m} \text { sprint } \\
\text { contract } \\
(\mathrm{s})\end{array}$ & $\begin{array}{c}\text { Difference } \\
(95 \% \mathrm{HDI})\end{array}$ & $\mathrm{ES}$ & $\mathrm{P}<0$ & $\mathrm{P}>0$ \\
\hline $\mathrm{U} 12$ & 2.79 & 2.77 & $\begin{array}{c}-0.02(-0.12, \\
0.09)\end{array}$ & 0.14 & 0.61 & 0.39 \\
$\mathrm{U} 13$ & 2.64 & 2.73 & $\begin{array}{c}0.09(0.00, \\
0.19)\end{array}$ & 0.60 & 0.08 & 0.92 \\
$\mathrm{U} 14$ & 2.57 & 2.65 & $\begin{array}{c}0.08(0.00, \\
0.16)\end{array}$ & 0.64 & 0.07 & 0.93 \\
$\mathrm{U} 15$ & 2.46 & 2.52 & $\begin{array}{c}0.06(0.00, \\
0.12)\end{array}$ & 0.64 & 0.13 & 0.87 \\
$\mathrm{U} 16$ & 2.49 & 2.50 & $\begin{array}{c}0.01(-0.06, \\
0.08)\end{array}$ & 0.10 & 0.37 & 0.63 \\
\hline
\end{tabular}

Difference $=$ estimated mean difference, $95 \% \mathrm{HDI}=95 \%$ higher density interval, $\mathrm{ES}=$ Cohen's $\mathrm{d}$ effect size, $\mathrm{P}>0$ probability the differences are greater than 0 (no contract group faster), $\mathrm{P}<0$ the probability the differences are less than 0 (contract group is faster). 
Table 11. Bayesian estimates of 30m sprint times at different ages between players who were subsequently successful in gaining a professional contract and players who did not gain a professional contract at an English category 2 football academy.

\begin{tabular}{|c|c|c|c|c|c|c|}
\hline $\begin{array}{l}\text { Age } \\
\text { group }\end{array}$ & $\begin{array}{c}30 \mathrm{~m} \text { sprint } \\
\text { no contract } \\
(\mathrm{s})\end{array}$ & $\begin{array}{c}30 \mathrm{~m} \text { sprint } \\
\text { contract } \\
\text { (s) }\end{array}$ & $\begin{array}{l}\text { Difference } \\
\text { (95\% HDI) }\end{array}$ & ES & $\mathrm{P}<0$ & $P>0$ \\
\hline U12 & 4.93 & 4.94 & $0.01(-0.15,0.13)$ & 0.00 & 0.46 & 0.54 \\
\hline U13 & 4.70 & 4.83 & $\begin{array}{c}0.13(-0.02 \\
0.28)\end{array}$ & 0.33 & 0.04 & 0.96 \\
\hline U14 & 4.53 & 4.69 & $0.15(0.01,0.29)$ & 0.67 & 0.02 & 0.98 \\
\hline U15 & 4.33 & 4.45 & $0.12(0.02,0.22)$ & 0.67 & 0.01 & 0.99 \\
\hline U16 & 4.33 & 4.30 & $\begin{array}{c}-0.03(-0.16 \\
0.11)\end{array}$ & 0.16 & 0.66 & 0.34 \\
\hline
\end{tabular}

Difference $=$ estimated mean difference, $95 \%$ HDI $=95 \%$ higher density interval, ES $=$ Cohen's d effect size, $\mathrm{P}>0$ probability the difference are greater than 0 (no contract group faster), $\mathrm{P}<0$ the probability the differences are less than 0 (contract group is faster).

Table 12. Bayesian estimates of countermovement jump (CMJ) at different ages between players who were subsequently successful in gaining a professional contract and players who did not gain a professional contract at an English category 2 football academy.

\begin{tabular}{ccccccc}
$\begin{array}{c}\text { Age } \\
\text { group }\end{array}$ & $\begin{array}{c}\text { CMJ } \\
\text { no contract } \\
(\mathrm{cm})\end{array}$ & $\begin{array}{c}\text { CMJ } \\
\text { contract } \\
(\mathrm{kg})\end{array}$ & $\begin{array}{c}\text { Difference } \\
(95 \% \mathrm{HDI})\end{array}$ & ES & $\mathrm{P}<0$ & $\mathrm{P}>0$ \\
\hline U12 & 35.7 & 34.2 & $-1.5(-4.5,1.5)$ & 0.31 & 0.17 & 0.83 \\
U13 & 38.7 & 35.7 & $-3.0(-6.2,0.0)$ & 0.52 & 0.03 & 0.97 \\
U14 & 41.2 & 38.8 & $-2.4(-5.5,0.9)$ & 0.55 & 0.06 & 0.94 \\
U15 & 45.9 & 41.4 & $-4.5(-8.1,-0.9)$ & 0.82 & 0.01 & 0.99 \\
U16 & 46.6 & 43.6 & $-3.0(-8.3,2.0)$ & 0.44 & 0.12 & 0.88 \\
\hline
\end{tabular}

Difference $=$ estimated mean difference, $95 \% \mathrm{HDI}=95 \%$ higher density interval; Effect Size $=$ Cohen's $\mathrm{d} ; \mathrm{P}>0$ probability the difference are greater than 0 (no contract group jumping higher), $\mathrm{P}<0$ the probability the differences are less than 0 (contract group jumping higher). 
Table 13. Bayesian estimates of arrowhead agility (AAT) times at different ages between players who were subsequently successful in gaining a professional contract and players who did not gain a professional contract at an English category 2 football academy.

\begin{tabular}{ccccccc}
\hline $\begin{array}{c}\text { Age } \\
\text { group }\end{array}$ & $\begin{array}{c}\text { AAT } \\
\text { no contract } \\
(\mathrm{s})\end{array}$ & $\begin{array}{c}\text { AAT } \\
\text { contract } \\
(\mathrm{s})\end{array}$ & $\begin{array}{c}\text { Difference } \\
(95 \% \text { HDI) }\end{array}$ & ES & $\mathrm{P}<0$ & $\mathrm{P}>0$ \\
\hline U12 & 9.09 & 8.82 & $-0.27(-1.50,0.76)$ & 0.81 & 0.80 & 0.20 \\
U13 & 8.73 & 8.80 & $0.07(-0.20,0.34)$ & 0.24 & 0.29 & 0.71 \\
U14 & 8.55 & 8.78 & $0.23(0.07,0.38)$ & 0.70 & 0.01 & 0.99 \\
U15 & 8.43 & 8.49 & $0.06(-0.11,0.24)$ & 0.23 & 0.24 & 0.76 \\
U16 & 8.29 & 8.26 & $-0.03(-0.20,0.14)$ & 0.13 & 0.66 & 0.34 \\
\hline
\end{tabular}

Difference $=$ estimated mean difference, $95 \% \mathrm{HDI}=95 \%$ higher density interval, $\mathrm{ES}=$ Cohen's d effect size, $\mathrm{P}>0$ probability the differences are greater than 0 (no contract group faster), $\mathrm{P}<0$ the probability the differences are less than 0 (contract group faster) 